\title{
Early Piast dynasty (10-11th century) stone architecture in western Poland in a geological context
}

\author{
Janusz SKOCZYLAS ${ }^{1, *}$ \\ 1 Adam Mickiewicz University in Poznań, Institute of Geology, Bogumiła Krygowskiego 10, 61-680 Poznań, Poland
}

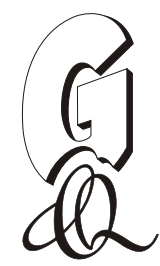

Skoczylas, J., 2017. Early Piast dynasty (10-11th century) stone architecture in western Poland in a geological context. Geological Quarterly, 61 (4): 765-770, doi: 10.7306/gq.1376

\begin{abstract}
There is no consistency in reporting the stone material used to construct the first structures in the early Piast dominion (10-11th century) in Poland. The role and importance of the type of the stone building material used at that time has been underappreciated if not completely ignored. It has been stated that glacial erratics comprise the fundamental rock material used in the early Middle Ages for building, representing up to $98 \%$ of construction material. The remaining rocks used in building construction included local calcareous sinter, bog iron ores, Jurassic limestone from the Piechciny-Barcin region and gypsum from a salt dome in the village of Wapno in western Poland, while Miocene sandstone excavated at the inception of the Polish state in the Brzeźno Quarry near Konin has received significant attention. There appear to have been distinct phases of use of the various types of rock material. There was likely a link between the development of tillage and the development of monumental stone architecture from the Middle Ages. Deforestation resulting from the development of agriculture helped expose the glacial erratics used in the stone architecture of the first Piast rulers.
\end{abstract}

Key words: glacial erratic, mortar, quartzite sandstone, gypsum, limestone, early Piast monumental architecture.

\section{INTRODUCTION}

Historians dealing with the origin of the Polish state have made little use of the results of geological research, one example of the scant exchange of knowledge between different scientific disciplines in Poland. This paper address some of these issues by means of specific objectives including:

- characterizing the rock material used in the first Piast churches and palaces, chiefly in Gniezno, Poznań and Ostrów Lednicki;

- indicating the places of origin of these raw materials;

- suggesting the probable directions of their distribution.

This text develops a lecture given at the Institute of European Culture of the Adam Mickiewicz University in Poznań in October 2015.

\section{THE EARLY PIAST STONE ARCHITECTURE IN THE LIGHT OF HISTORICAL NARRATION}

Research into the rock material used in the construction of early medieval stone structures, sacral and secular alike, goes back to at least the second half of the 19th century (Skoczylas, 1990). To date, though, there has been little mention of the construction material used to build the first stone structures in Po-

*E-mail: skocz@amu.edu.pl

Received: February 17, 2017; accepted: June 12, 2017; first published online: August 25, 2017 land, despite the many historical and archaeological papers published during the 1050th anniversary of Poland's birth (AD 966).

The development of the use of rock material to construct stone buildings has attracted only a few remarks on the part of art historians and architects (Świechowski, 2000, 2009). The adoption by Mieszko I of Christianity (AD 966) may be regarded as Poland's more or less decisive step into the civilised realm of the western world. It was manifested in part through constructing monumental (by medieval standards) structures, both sacral and secular.

Since the mid-19th century, it has been commonly held that the early Romanesque structures were built from dry stone, although much earlier Staszic (1815) made reference to "discarded boulders". However, it was not until Świechowski's publication (1950) that the use of granite in architecture was mentioned. Lately, Buko (2011) noted that gneiss was also used in early medieval buildings.

This simplification in considering the role of the rock material involved in these early Romanesque structures has been compounded by failure to understand, recognize and differentiate the quality of mortar used in these structures. For example, Urbańczyk (2012: p. 247) stated: ".... the Poznań baptismal ba$\sin$ is just a proof of mixing large quantities of gypsum mortar by means of a method still used in traditional buildings". However, the Poznan "baptismal basin" is made of lime rather than gypsum mortar as Urbańczyk (2008a, b, 2016) has noted (Fig. 1).

Furthermore, in disputing the view of Rodzińska-Chora y (1993), Urbańczyk (2013: p. 327) noted that baptismal basins in Ostrów Lednicki were made from lime mortar, though it has been shown that these baptismal basins (just like the entire mortar in the palace and church complex at Ostrów Lednicki) were made from gypsum ( urowska, 1993; Skoczylas, 2014). 


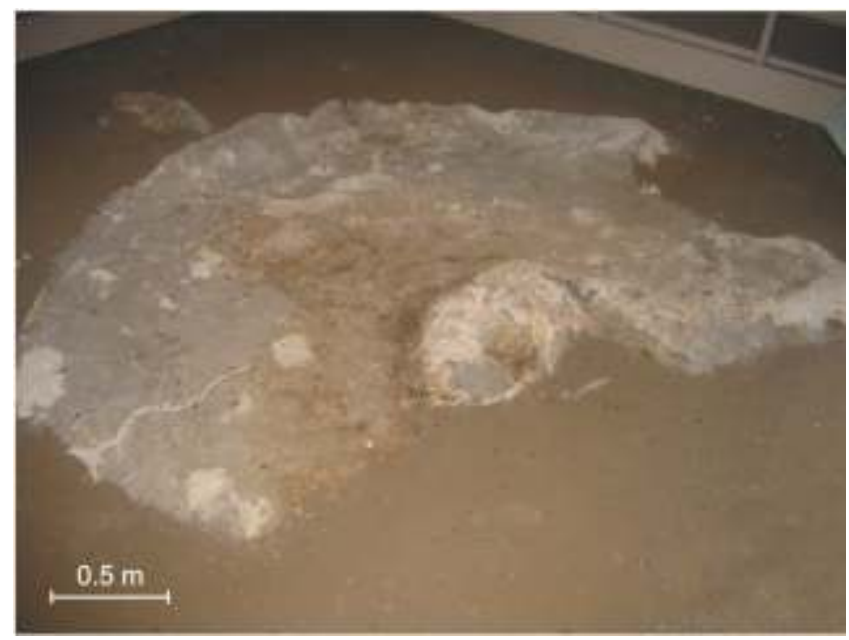

Fig. 1. Poznań, Ostrów Tumski; the basement of Poznań cathedral; a piece of a lime baptismal basin (Kurnatowska, 1998)

\section{ROCK MATERIAL AS THE MAJOR CONSTRUCTION MATERIAL USED IN THE EARLY PIAST STRUCTURES}

The type and quality of the stone construction material used in the church and palace complexes built by the first Piast rulers in the region of Wielkopolska was determined by the geological composition of the Polish lowlands. Ice sheets transported rock debris from Scandinavia and deposited this material in the form of clay, loam, silt, sand and gravel as well as glacial erratic boulders. This formed the main available rock material used in those pioneering times of Polish stone construction.

The rock material identified in the early Piast structures indicates that glacial erratics were favoured, sometimes following some mechanical processing. The demand for hard crystalline rocks was greatest. This was likely largely by surface collection, though the amount of rock needed at any time may have led to attempts at excavation.

The boulders were probably collected from nearby the constructions; given their abundance they were used in the foundations and walls of all the early Piast structures (Skoczylas, 1990, 2016).

In this case, pragmatism took preference over any perceived magical properties and the tradition that associated such boulders, that we now know were brought in by ice sheets, with any putative extra-terrestrial or supernatural qualities. Their distinctive compositions may have raised distrust and caution. However, there was interest in their weight, sizes, colours and resistance to impact. Since they could be transferred, arranged, split and broken, they were referred to as "live stones" (Pazdur, 1991; Kóčka-Krenz, 2012).

The first breach in the tradition related to the symbolism of glacial erratics occurred at the stage of building the gord fortifications where large loose boulders of this kind were used to reinforce the fortifications. They ensured the stability and durability of these defensive structures. These experiments in building, most probably dating back to the early 10th century, were copied and used, this time not only to build fortifications but predominantly to build stone structures.

It is hard to say today what was the significance and the role of the first builders and those who sought out, glacial rocks, as there are no traces left of the names of the craftsmen and other employees involved in the construction work, which represented a new form of economic expansion (Pazdur, 1991).

Construction of the huge churches and palaces attracted admiration, recognition and sometimes fear of the new reality and of the new rule, both secular and religious. The "mute stones" in great numbers and even greater mass, skilfully arranged to form specific structures, were symbols of this "new deal". They made the society aware that stone buildings provided a new civilisational challenge which required acceptance and adjustment to the new way of thinking and acting, the new faith. Therefore, they served as a new determinant of the progress of civilization.

At many locations, primarily in Ostrów Tumski in Poznań, in Gniezno, Ostrów Lednicki, Giecz, Łekno, Trzemeszno, Mogilno, Kruszwica, Strzelno and Lubin near Gostyń (Fig. 2), the stone material identified in the remains of the early Piast architecture indicates that they consisted primarily (88 to $98 \%$ ) of glacial erratics. Macroscopic analysis has identified at least 20 types of rock with a prevalence of quartzite sandstone and quartzite $(\sim 37 \%)$ followed by gneiss $(26.4 \%)$ and granite (24.4\%). The remaining dozen or so types of glacial erratic such as porphyry, syenite, diorite, pegmatite, aplite and amphibolite may represent up to $12 \%$ of the preserved and identified stone building material. Despite the diversity of the stone building material in the specific structures, in general the composition revolves around quartzite-gneiss-granite (Fig. 3) (see Skoczylas, 1990, 1994 for statistical details).

For example: in the church and palace complex in Ostrów Lednicki, 18 types of rocks were identified with sandstone and quartzite prevailing $(58.8 \%)$, followed by gneiss $(22.5 \%)$ and granite $(8.3 \%)$. The slightly younger gord church at Ostrów Lednicki consists of $15.8 \%$ granite and as little as $8.1 \%$ of gneiss but as much as $50.3 \%$ erratic sandstone and quartzite. However, the church's foundation was built with bog iron ores, a geologically local material i.e. not brought by ice sheets but originated in situ once the glacier subsided.

Other rocks brought in by the ice sheets were used in the construction of the early Piast structures, mixed with sand and gravel as well as clay. Sand was used as a thinning additive to mortar and ceramic objects. Clay was sporadically used to bind large glacial erratics used in the foundations of the first structures, and was commonly used in production of utensils and ceramic objects. Later, from the second half of the 12th century it was used predominantly to manufacture bricks. Glacial erratics underwent only some basic processing at the surface. In situ rocks included Neogene coloured loam from Poznan binding the foundation of the church at Lubin near Gostyń. Little is known about the used of the associated marlstone or gyttja. Perhaps, like the other types of limestone (including calcareous sinter), these were used to produce carbonate-based mortar. The role and importance of calcareous sinter in early medieval construction was much greater than that of marlstone and gyttja. It was used as a basic material of the architecture, around the doors and windows, less frequently in church ceilings and the sides of wells and tombs (Skoczylas, 1990, 2016; Fig. 4). In the Polish lowlands, calcareous sinter has been identified at Fordon (now a district of Bydgoszcz), Głowiny near Dobrzyń and Trlagg near the Pakość Reservoir (Jochemczyk and Skoczylas, 1991). Bearing in mind the geographic location, most probably the calcareous sinter from the structures described in this text came from Trląg.

Bog iron ores were used not only to produce weapons, tilling tools and household objects but also in construction. Much bog iron ore was used as construction material in the foundation and the wall bases of the gord church in Ostrów Lednicki 


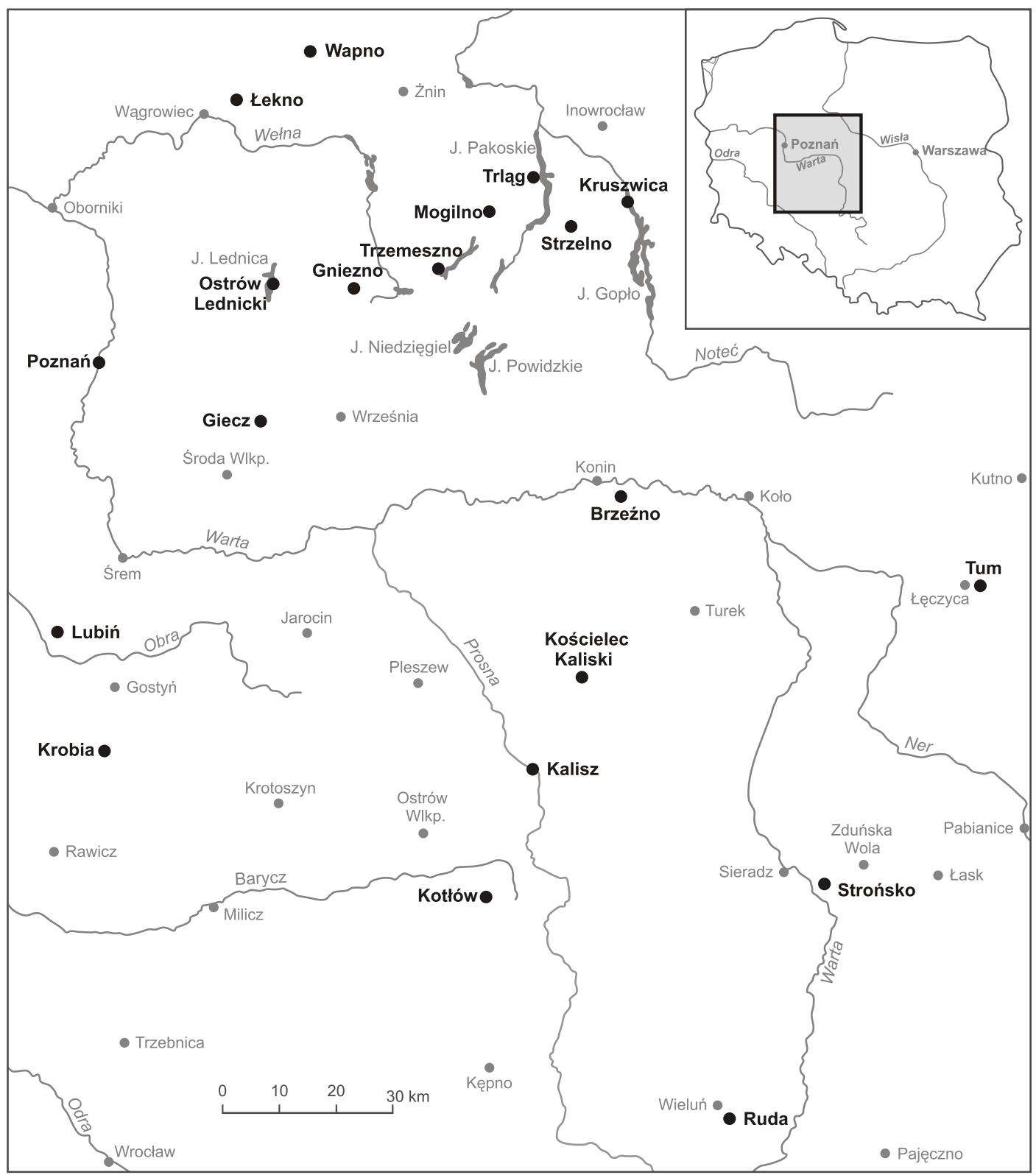

Fig. 2. Study area

(Kraczkowska and Rzepa, 2000). Pieces of bog iron ore have also been identified in the embankment or dyke surrounding the gord at Ostrów Tumski in Poznań.

These examples show how the geological conditions of the Polish lowlands, including those of the area where the Polish state originated, determined the type, quality and frequency of use of rock material. The area is covered be glacial and post-glacial deposits up to $200 \mathrm{~m}$ thick, and there are only a few places where older, harder rocks come to or close to the surface. The Miocene sandstone in the Konin and Ostrzeszów areas are examples, together with the Cretaceous limestone from the Uniejów area, the Jurassic limestone from Barcin-Wapienno-Piechcin near Inowrocław and the Permian (Zechstein) gypsum outcrops at Wapno near Wagrowiec. The outcrops of all these rocks were exploited in the Middle Ages for building.

Neither Jurassic nor Cretaceous limestone rocks were identified in the stone remains of the early medieval structures studied. This is largely due to the re-use of the material later to produce limestone mortar for other buildings. Cretaceous lime- stone was used to produce early medieval spindle whorls; some specimens may be seen at Ostrów Lednicki. However, the nature of the rock material used to produce lime mortar needs further study. Gypsum identified in the structures in Giecz, Poznań, Ostrów Lednicki, Gniezno and Łekno comes from a salt dome at Wapno near Wagrowiec (Skoczylas, 2014; Fig. 5)

Miocene sandstone from Brzeźno near Konin has been used. In the early medieval stone architecture, glacial erratics prevailed. They represent the construction material of the foundations as well as the inner and outer walls. However, they could rarely be used for the architectural elements or around the doors or windows. The erratics, collected and gathered at the construction site, had various sizes, weight, shapes, colours and physical and technical properties. Therefore, other compact and hard rocks, such as the sandstone from Brzeźno, with more consistent technical properties, and with homogeneous aesthetic properties and a uniform colour, were valued and coveted.

A geological, landscape and historic park should be established in the outcrop of the Miocene sandstone, representing 


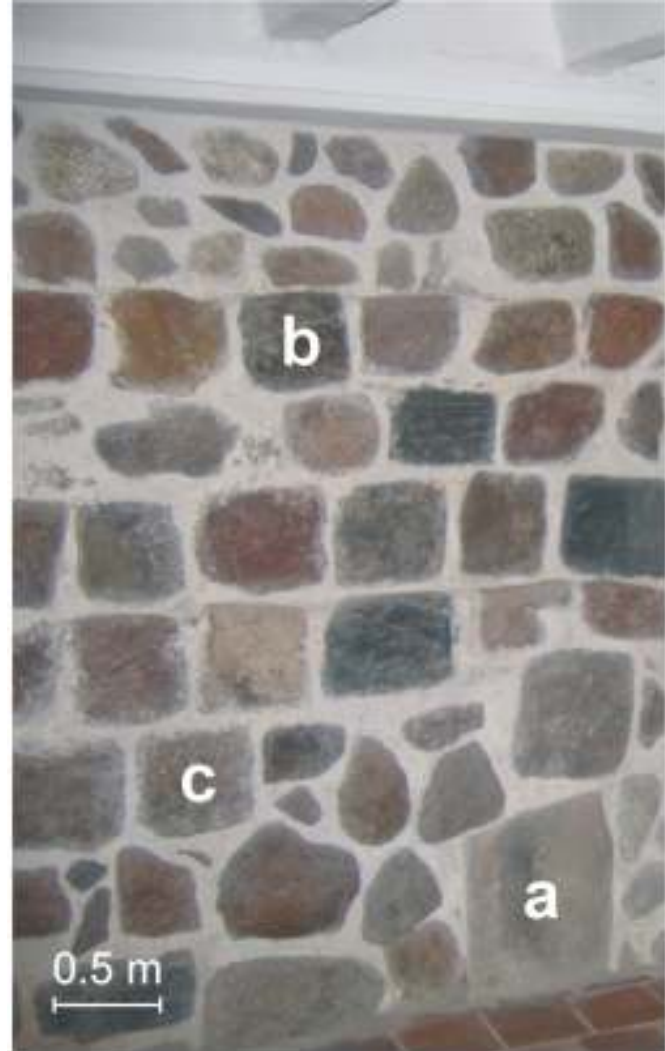

Fig. 3. Gniezno

An example of the remains of walls made of quartzite, gneiss and granite, separating the nave from an aisle of the Romanesque cathedral ( $a$ - quartzite, $b$ - gneiss, $c$ - granite)

the quarry from which the material was excavated. The park would protect this place of importance to Poland's natural cultural heritage (Skoczylas, 2003).

The excavation of rock material in the Konin area in the early Middle Ages is seen in the oldest Romanesque milepost (Łuszczkiewicz, 1891; Dunin-Wąsowicz, 1970; Wędzki, 1979, 1980, 1981). The milestone's popularity, importance and status (even today) was reflected on 5 February 2008, when the National Bank of Poland launched a PLN 2.00 coin with an image of the milestone (Skoczylas, 2008).

Research carried out to identify the architectural elements made from the Brzeźno sandstone in the early Middle Ages and to map them was published by Skoczylas $(1990,1994)$. The quartzite sandstone from Brzeźno served as the material for architectural elements of significant sacral structures as well as the palace and church complexes at Poznań, Ostrów Lednicki, Gniezno, Trzemeszno, Mogilno and Strzelno. Subsequent research by Kasprzak (2006) and Szczepaniak (2015) indicated that the Brzeźno sandstone was used in large quantities as a construction material in churches at Kościelec Kaliski and Kalisz, and to a lesser extent at Kotłów (Figs. 6 and 7).

Similar research was carried out in the area east of Konin by Krystek (2010). This indicated that some architectural elements in the church at Tum near Łęczyca (65 km in a straight line), in Strońsko between Sieradz and Zduńska Wola $(81 \mathrm{~km})$ as well as Ruda near Wieluń $(111 \mathrm{~km})$ had been made from the same Brzeźno sandstone (Fig. 7), which is also used in the interior design of modern era churches in the near vicinity of Konin (Budkiewicz, 2010).

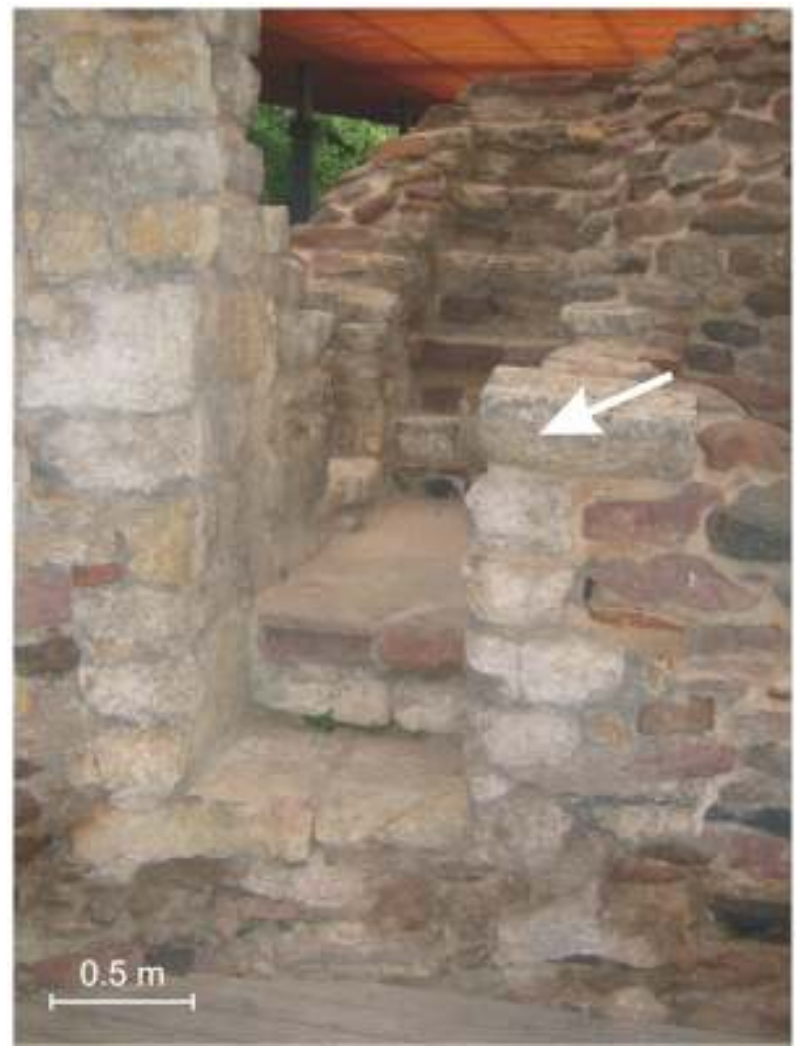

Fig. 4. Ostrów Lednicki

An example of blocks of calcareous sinter used around the passage between the chapel and the palace of Mieszko I and Bolesław Chrobry

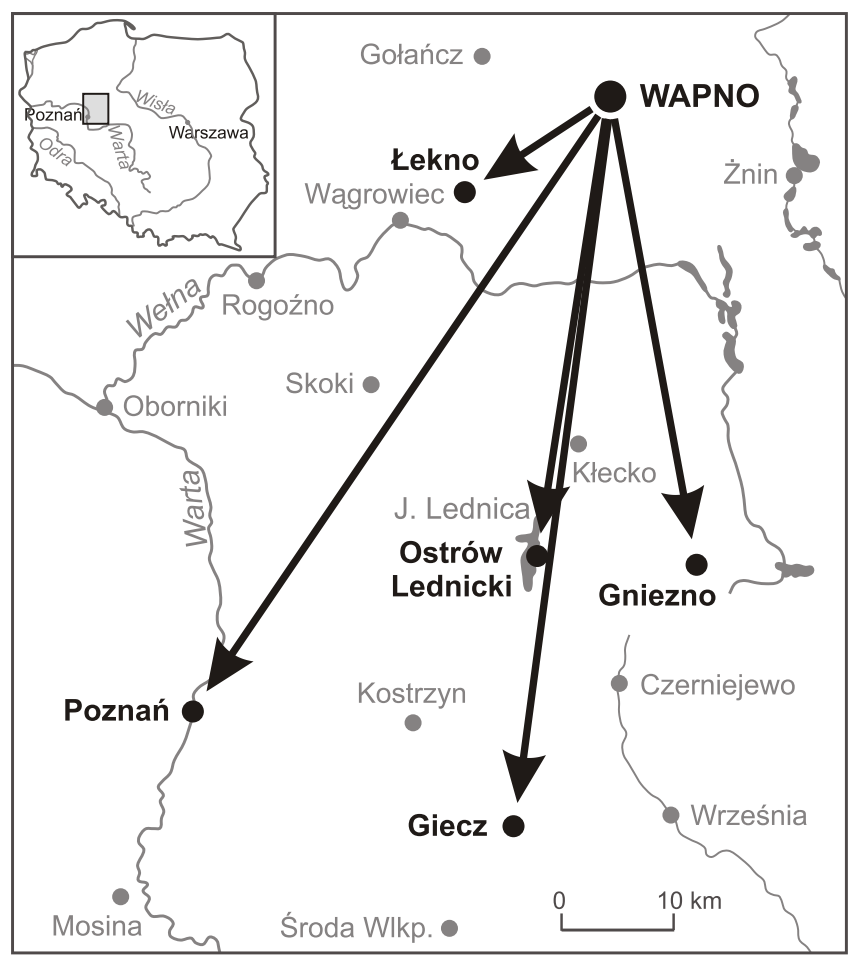

Fig. 5. Attempted reconstruction of the directions of distribution of gypsum from Wapno village in the early Middle Ages 


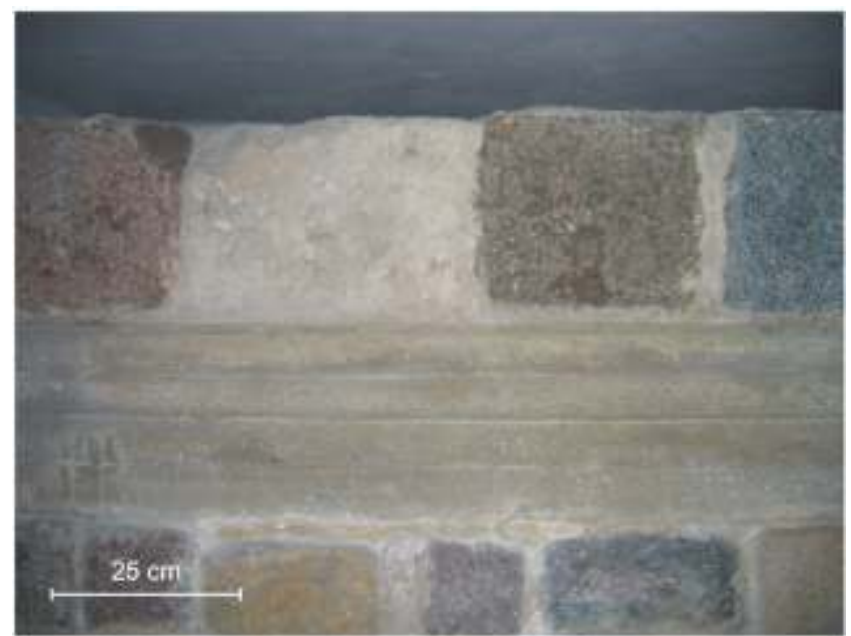

Fig. 6. Poznań, Ostrów Tumski; the basement of Poznań cathedral; a piece of pillar II of the Romanesque church; starting from the upper left corner: granite, calcareous sinter, granite, granite, in a large slab of sandstone from Brzeźno

\section{SUMMARY}

In the course of surveying and identifying the stone building material in the remains of the early Piast palace and church complexes, the use of the raw material can be divided into several stages.

In the initial structures, only glacial erratics were used, chiefly Jotnian sandstone bound with gypsum mortar (the palace and church complexes at Ostrów Tumski in Poznań - the Dąbrówka palace and chapel, Mieszko and the Bolesław Chrobry palace and chapel at Ostrów Lednicki).

1. Calcareous sinter was used to frame the doors and windows.

2. Sandstone from Brzeźno was used, worked by an iron chisel.

3. There was a gradual replacement of gypsum mortar with carbonate (lime) mortar.

4. In one case, glacial erratics were replaced by bog iron ore as the building material (the gord church at Ostrów Tumski).

In the course of establishing the Polish state, environmental conditions underwent profound change. The large-scale trend to build, in the first half of the 10th century, gords surrounded by embankments reinforced with wood resulted in deforestation of

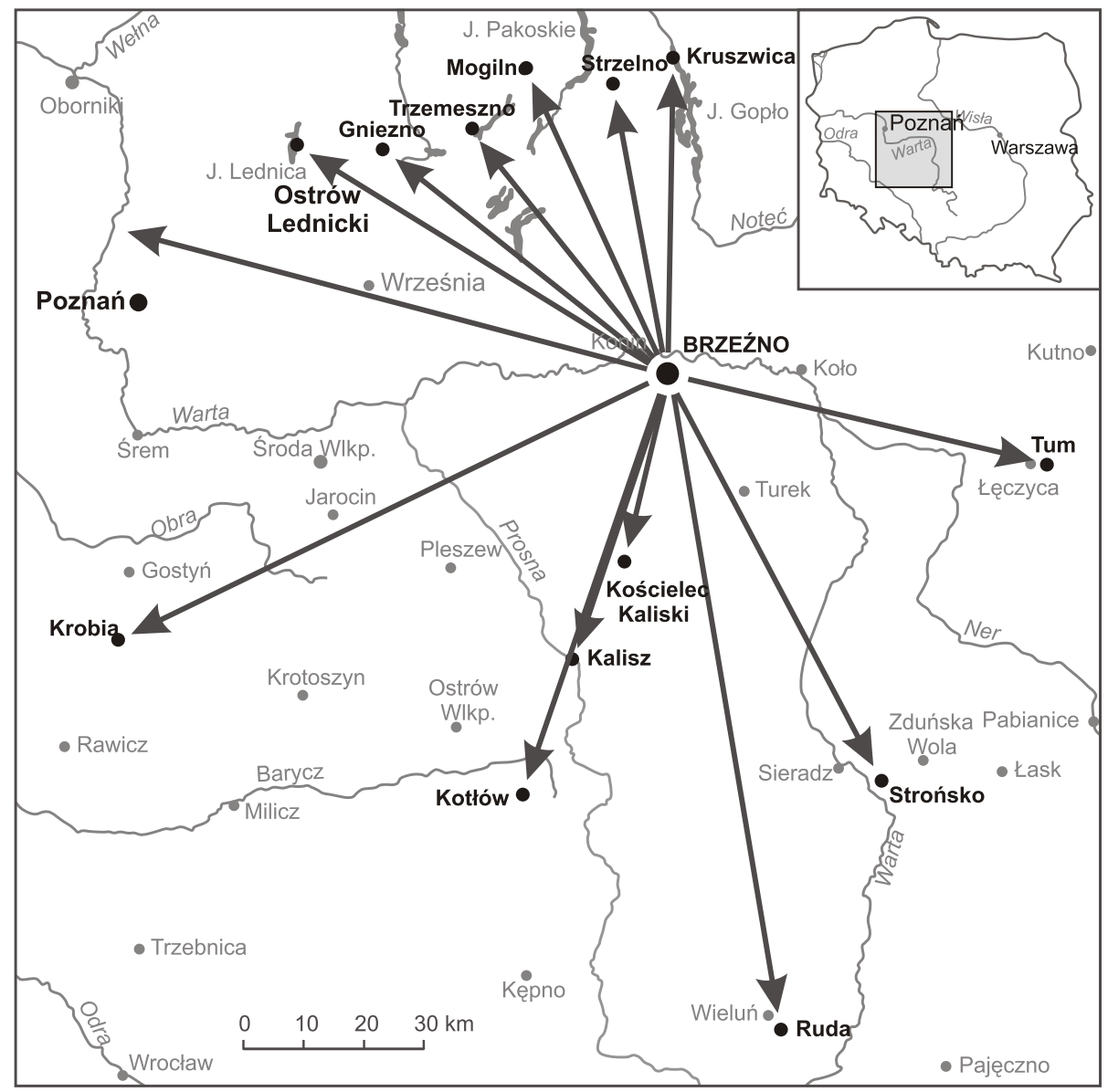

Fig. 7. Attempted reconstruction of the directions of distribution of the Miocene sandstone from Brzeźno near Konin in the early Middle Ages 
the gords' surrounds. Tillage or, to be more precise, preparation of extensive land for growing crops and breeding animals, was also conducive to deforestation. As large stretches of land were exposed, it was easier to obtain rock material for construction. In the first half of the 10th century, the exposed erratic material was used to reinforce the bases of the embankments around the gords. Between the late 10th century and the mid-13th century, the exposed rocks were used to construct the first monumental stone structures in the first Piast dominion. A formerly overlooked link between the development of tilling and the emergence of the monumental early Piast structures has been discovered.

The early medieval deforestation of large areas of what is now referred to as the Wielkopolska region may have stemmed solely from land cultivation, though a further factor may have been the need to find glacial erratics used to build monumental stone structures. The beginning of the Piast state was marked by the characteristic process of "destoning" the natural environment. The "destoning" of inanimate natural resources (chiefly by collecting, storing and using glacial erratics) was accompanied by the emergence of the new stone infrastructure of early medieval human abodes.

Acknowledgements. The author would like to thank Prof. S. Wołkowicz and two anonymous reviewers for their valuable suggestions to improve this manuscript.

\section{REFERENCES}

Budkiewicz, M., 2010. Brzeźno (in Polish). Mariusz Budkiewicz. Brzeźno.

Buko, A., 2011. Archeologia Polski średniowiecznej (in Polish). Wydawnictwo TRIO, Warszawa.

Dunin-Wąsowicz, T., 1970. Topografia wczesnośredniowiecznego regionu konińskiego w świetle badań hydrograficznych (in Polish). In: Z dziejów regionu konińskiego (ed. A. Kotuła): 57-75. Zakład Narodowy im. Ossolińskich.

Jochemczyk, L., Skoczylas, J., 1991. Petrographic studies of the bonding substances from early medieval building from Ostrów Lednicki (in Polish with English summary). Przegląd Geologiczny, 39: 345-349.

Kasprzak, M., 2006. Zró nicowanie, pochodzenie i wykorzystanie piaskowców w romańskiej architekturze południowej Wielkopolski (in Polish). Ph.D. thesis. UAM Archive, Poznań

Kóčka-Krenz, H., 2012. Na wyspie Ostrów, przy której, jest dziś Poznań (in Polish). Muzeum Archeologiczne w Poznaniu, Poznań.

Kraczkowska, I., Rzepa, G., 2000. Charakterystyka rud darniowych ze ścian jednonawowego kościoła na Ostrowe Lednickim (in Polish). In: Przewodnik LXXI Zjazdu Polskiego Towarzystwa Geologicznego (eds. J. Biernacka and J. Skoczylas): 278-281. Bogucki Wydawnictwo Naukowe, Poznań.

Krystek, M., 2010. Zró nicowanie, wykorzystanie i pochodzenie piaskowców w budowlach regionu łódzkiego (in Polish). Ph.D. thesis. UAM Archive, Poznań.

Kurnatowska, Z., 1998. Poznańskie baptysterium (in Polish). Slavia Antiqua, 39: 51-69.

Labuda, G., 2002. Mieszko I (in Polish). Wydawnictwo Ossolineum, Wrocław-Warszawa-Kraków.

Łuszczkiewicz, W., 1891. Kościół romański we wsi Stare Miasto pod Koninem. Słup drogowy w Koninie. Kościół w Kazimierzu (in Polish). Sprawozdanie Komisji do badania historii sztuki w Polsce, 6: 23-33.

Pazdur, J., 1991. Rola cywilizacyjna kamienia w Polsce średniowiecznej (in Polish). In: Kultura średniowieczna i staropolska. Studia ofiarowane Aleksandrowi Gieysztorowi w 50-lecie pracy naukowej (ed. D. Gawinowa): 55-65. PWN, Warszawa.

Rodzińska-Chorą y, T., 1993. Baptysterium (in Polish). In: U progu chrześcijaństwa w Polsce. Ostrów Lednicki. Gutenberg, Kraków: 103-167.

Skoczylas, J., 1990. U ytkowanie surowców skalnych we wczesnym średniowieczu w północno-zachodniej Polsce (in Polish). Uniwersytet im. Adama Mickiewicza. Seria Geologia, (12).

Skoczylas, J., 1994. U ytkowanie surowców skalnych w początkach państwa polskiego w Wielkopolsce (in Polish). In:
U ytkowanie surowców skalnych w początkach państwa polskiego (ed. J. Skoczylas): 63-84. Wydawnictwo Naukowe UAM, Poznań

Skoczylas, J., 2003. Wykorzystanie piaskowca z Brzeźna we wczesnośredniowiecznym budownictwie (in Polish). In: FNP dla archeologii. Podsumowanie programów TRAKT i ARCHEO. Wydawnictwo UMCS, Lublin: 40-44.

Skoczylas, J., 2008. Słup na rewersie (in Polish). Świat kamienia, (52): 90.

Skoczylas, J., 2014. Gipsowe zaprawy murarskie w poczatkach państwa polskiego (in Polish). Slavia Antiqua, 55: 171-178.

Skoczylas, J., 2016. Kamień w państwie pierwszych Piastów (in Polish). Wydawnictwo Naukowe CONTACT/ABC, Gniezno.

Staszic, S., 1815. O ziemiorodztwie Karpatow i innych gor i rownin Polski (in Polish). Reprint. Wyd. Geol., Warszawa, 1955.

Szczepaniak, M., 2015. Procesy diagenetyczne w wybranych piaskowcach Dolnego Śląska i ich znaczenie dla romańskiej architektury południowej Wielkopolski (in Polish). Bogucki Wydawnictwo Naukowe, Poznań.

Świechowski, Z., 1950. Architektura granitowa Pomorza zachodniego w XIII wieku (in Polish). Prace Komisji Historii Sztuki, 2.

Świechowski, Z., 2000. Architektura romańska w Polsce (in Polish). Wydawnictwo DIG, Warszawa.

Świechowski, Z., 2009. Katalog architektury romańskiej w Polsce (in Polish). Wydawnictwo DIG, Warszawa.

Urbańczyk, P., 2008a. Trudne początki Polski (in Polish). Wydawnictwo Uniwersytetu Wrocławskiego, Wrocław.

Urbańczyk, P., 2008b. Władza i polityka we wczesnym średniowieczu (in Polish). Wydawnictwo Uniwersytetu Wrocławskiego, Wrocław.

Urbańczyk, P., 2012. Mieszko I the Mysterious (in Polish with English summary). Wydawnictwo Naukowe Uniwersytetu Mikołaja Kopernika, Toruń

Urbańczyk, P., 2013. Myśli o średniowieczu (in Polish). Wydawnictwo Templum, Wodzisław Ślaski.

Urbańczyk, P., 2016. Co się stało w 966 roku? (in Polish). Wydawnictwo Zysk i S-ka, Poznań.

Wędzki, A., 1979. Początki Konina (in Polish). Rocznik Koniński, 7: 9-41.

Wędzki, A., 1980. Konin w późnym średniowieczu (in Polish). Rocznik Koniński, 8: 7-37.

Wędzki, A., 1981. Przemiany przestrzenne Konina w czasach nowo ytnych (in Polish). Rocznik Koniński, 9: 41-93.

urowska, K. ed., 1993-1994. U progu chrześcijaństwa (in Polish). Ostrów Lednicki, 1-2. Gutenberg, Kraków. 